\title{
ЗМІНИ В УНОРМУВАННІ ВІДМІНКОВИХ ЗАКІНЧЕНЬ ІМЕННИКІВ НА ТЛІ СУЧАСНОЇ МОВНОЇ ПРАКТИКИ УКРАЇНСЬКОЇ ПРОФЕСІЙНОЇ СПІЛЬНОТИ
}

Проаналізовано основні зміни в морфологійних нормах сучасної украӥнської літературної мови, зафіксовані в новому «Українському правописі» 2019 р. Простежено зумовленість цих змін історично сформованими граматичними особливостями української мови. Залежно від ступеня істотности всі запропоновані зміни диференційовано на власне зміни та корекціі. Констатовано неоднаковий зв'язок власне змін і корекцій в унормуванні відмінкових закінчень іменників із сучасною мовною практикою украйнської професійної спільноти: одні з них засвідчені в ній ще до їх кодифікації в новому «Украйнському правописі», другі, унаслідок граматичного спадку, сформованого в радянський період, та деструктивного впливу людського чинника, ще слабко підтримані мовною практикою професійної спільноти, а треті в мовній практиці украӥнців представлені значно ширше, ніж иче відбито в чинному «Украйнському правописі».

Ключові слова: морфологійні норми, іменник, відмінок, закінчення, «Украйнський правопис», мовна практика, професійна спільнота.

Формулювання наукової проблеми та обгрунтування актуальности їі розгляду. За своїм призначенням «Український правопис» - це передусім збірник орфографічних та пунктуаційних правил української літературної мови. Він, як зауважував О. Синявський, у жодному разі не повинен заступити систематичні курси української граматики, а має тільки полегшити й угрунтувати їх появу та розвиток (Синявський 2004: 451). Проте за понад сторічний період функціювання «Українського правопису» уже стало традицією, крім орфографічних і пунктуаційних, подавати в ньому також правила, що стосуються морфологійних норм і насамперед тих, які пов’язані з відмінюванням слів. Хоч граматичну систему української літературної мови діти та юнацтво вивчають у школах, гімназіях, коледжах, розділ «Правопис закінчень відмінюваних слів» досі збережений у найголовнішому орфографічному кодексі України. На думку В. В. Німчука, це зроблено для того, щоб запобігти «подальшій суржикізації граматичної системи української мови», у формі уваг, приміток, виділених прикладів, уведених до тексту «Українського правопису», застерегти користувачів від уживання типових позанормативних граматичних елементів (Німчук 1999: 298).

У новому «Українському правописі» 2019 р. найпомітніші зміни в кодифікації морфологійних норм сучасної української літературної мови також стосуються відмінкових закінчень іменників. Проте більшість із цих змін не є кардинальними, вони переважно видозмінюють (удокладнюють, уточнюють тощо) морфологійні норми, викладені в попередніх редакціях «Українського правопису». Оскільки до «Українського правопису» 2019 р. була чинна його редакція, опублікована в 1993 р., то ми порівнюватимемо зміст аналізованих морфологійних норм у цих двох виданнях.

Аналіз публікацій із досліджуваної проблеми. Суперечки навколо правописних питань серед української наукової спільноти тривають давно. Найгостріші дискусії спричиняють принципи правописотворення, зокрема їх опертя, з одного боку, на об’єктивні, історично сформовані особливості розвитку української літературної мови, а з іншого, на ті вже досить тривкі традиції, які склалися в мовній практиці українців. У зв'язку із цим українські мовознавці неодноразово звертали увагу, що деякі морфологійні норми, кодифіковані в попередній редакції «Українського правопису», потребують перегляду й корегування (Бурячок 1997: 27 
28; Горняткевич 1997: 42-43; Баранник 1997: 76-78; Пономарів 1997: 79-80; Головащук 1997: 81-86 та ін.).

У пропонованій статті ставимо за мету проаналізувати основні зміни в унормуванні відмінкових закінчень іменників, зафіксовані в новому «Українському правописі» 2019 р., на тлі історично сформованих граматичних особливостей української мови та сучасної мовної практики так званої професійної спільноти - «освітян, працівників засобів масової комунікації, офіційно-ділової сфери та інших верств освічених носіїв української мови» (Городенська 2017: 40), тобто людей, які мають фахові знання з української мови й дотримуються літературних мовних норм у своїй професійній діяльності. Представники професійної спільноти свідома частина українського мовного соціуму, що, на противагу загалові представників мовної непрофесійної практики, обізнана 3 причинами внесення змін до «Українського правопису», знає ці зміни і спроможна їх оцінити.

Реалізація цієї мети передбачає розв'язання таких завдань: 1) з'ясувати перелік основних змін в унормуванні відмінкових закінчень іменників, унесених до нового «Українського правопису» 2019 р.; 2) залежно від ступеня істотности диференціювати ці зміни на власне зміни й корекиї; 3) проаналізувати їх у контексті історично сформованих граматичних особливостей української мови; 4) простежити зв'язок запропонованих змін та корекцій із сучасною мовною практикою української професійної спільноти.

Об'сктом дослідження $є$ відмінкові закінчення іменників сучасної української літературної мови; предметом - зміни та корекції в унормуванні відмінкових закінчень іменників, зафіксовані в новому «Українському правописі», їх зв’язок із сучасною мовною практикою української професійної спільноти.

Опис фактичного матеріалу та методів, застосованих у процесі аналізу. Фактичним матеріалом виконаного дослідження послугували 2 групи морфологійних форм іменників: 1) відмінкові форми іменників, зафіксовані в «Українському правописі» різних років видання; 2) відмінкові форми іменників, активно вживані в сучасній мовній практиці української професійної спільноти.

Дослідження виконано за допомогою загальнонаукових (спостереження, аналіз, синтез, порівняння, систематизація) та власне-лінгвістичних методів, основними серед яких $є$ описовий (викладення власне змін і корекцій в унормуванні відмінкових закінчень іменників) та зіставний (порівняння відмінкових форм іменників, наведених у тексті «Українського правопису» 2019 р., 3 іменниковими словоформами, уживаними в сучасній мовній практиці української професійної спільноти) методи.

Наукова новизна дослідження полягає у виокремленні та аналізуванні основних морфологійних змін у новому «Українському правописі» 2019 р.

Теоретичну цінність отриманих результатів становить обгрунтування передумов змін у кодифікації відмінкових закінчень іменників, унесених до нового «Українського правопису» 2019 р., на тлі історично сформованих граматичних особливостей української мови та сучасної мовної практики професійної спільноти.

Практичну цінність одержаних результатів убачаємо в тому, що висновки, зроблені на підставі аналізу зв'язку основних змін у морфологійних нормах сучасної української літературної мови $з$ тенденціями, які поширилися в професійній українськомовній практиці 3 початку 90-х рр. XX ст. і сьогодні тривають далі, прислужаться під час подальшого внормування відмінкових закінчень іменників.

Виклад основного матеріалу й обгрунтування результатів дослідження. Усі видозміни в тексті «Українського правопису» 2019 р. залежно від ступеня їх істотности поділяємо на власне зміни - нові правила, яких не було в «Українському правописі» 1993 р., та корекиіїуточнення, удокладнення, переформулювання змісту правил, наявних у попередній редакції правописного кодексу, запровадження варіантних морфологійних форм, розширення ілюстративного матеріалу тощо. 
Як власне зміни в новому «Українському правописі» можна кваліфікувати нові правила написання закінчень: родового відмінка однини деяких іменників - назв населених пунктів чоловічого роду II відміни; родового відмінка однини частини іменників жіночого роду III відміни та всіх іменників III відміни, що закінчуються на -mb із попереднім приголосним; кличного відмінка однини окремих іменників - особових імен чоловічого роду II відміни; кличного відмінка однини іменників чоловічого роду II відміни та іменників жіночого роду I відміни у звертаннях, що складаються з двох назв. Корекції зроблено щодо правопису закінчень знахідного і місцевого відмінків однини та називного відмінка множини іменників чоловічого роду II відміни, а також знахідного відмінка множини іменників - назв тварин жіночого роду І відміни.

У новому «Українському правописі» 2019 р., на відміну від «Українського правопису» 1993 р., у родовому відмінкові однини зафіксовано зміни в уживанні закінчень іменників чоловічого роду II відміни, що $є$ назвами населених пунктів на зразок Амстердам, Гомель, Ліверпуль, Лондон, Мадрид, Париж, Чорнобиль, тобто крім тих, що мають суфікси -ськ-, -цькк-, -ець-, форманти -бург-, -град- (-город-), -піль- (-поль-), -мир-, -слав-, -фурт-, а також крім назв населених пунктів і різних географічних назв із наголосом у родовому відмінку на кінцевому складі та із суфіксами присвійности -ів- (-їв-), -ев- (-єв-), -ов-, -ин- (-ін-), -ач-, -ич(Український правопис 2019: 114). Якщо в редакції «Українського правопису» 1993 р. нормативним закінченням родового відмінка однини цих іменників було - $a(-я)$ (Український правопис 1993: 68), то в «Українському правописі» 2019 р. для них кодифіковано обидва варіанти закінчень - -a (-я) та -y (-ю) (Український правопис 2019: 117). Ця зміна перегукується із правилом, поданим в «Українському правописі» 1928 р., відповідно до якого «від іменниківназов місцевостей, країв, річок, міст тощо родовий однини вживається то $3-y$, -ю (далеко частіше), то з -а, -я: <..> Берліну, Лондону, Парижу, Риму, Нью-Йорку, Херсону» (Український правопис 1929: 35), і спирається на наявність форм родового відмінка на -y (-ю) в іменників назв населених пунктів в українській мовній практиці: фольклорі, художній літературі, наукових текстах та публіцистиці, пор.: Вези овес хоч до Парижу, а не буде з вівса рижу [рису] (Укр. присл.); [Кирило :] То все брехня! Нема: ні Лондуму, ні Парижу!.. (М. Кропивницький); І тисячі-тисячі свідків з Києва, Харкова, Львова, Праги, Берліну, Риму, Парижу (У. Самчук); Дощчовий вітряний день, Москва, ждемо вильоту до Нью-Йорку (О. Гончар); Студії украйнської мови в Мюнхенському університеті почалися тільки від кіния війни, 1945 року, коли до Мюнхену прибула з Берліну Ганна Наконечна (Ю. Шевельов) та ін.

У мовному повсякденні XXI ст. тенденція вживати іменників - назв населених пунктів у родовому відмінкові однини із закінченням -y (-ю) активізувалася (Теоретична... 2004: 109; Тараненко 2005: 91). Її засвідчують передусім засоби масової комунікації та художня література, пор.: ...незабутня подорож на двох до романтичного Парижу (інтернетівська газета «Версії», 2013); Однак, до Нью-Йорку, де проходить битва за чемпіонський титул, Карякін вирушав із надією, точніше, з шансом на перемогу (газета «Україна молода», 24.11.2016); Безконечні засідання вчених рад, <..> збирання підписів під рекомендаційними листами зі Стокгольму, Парижу й Лондону і насамкінець - конфіденційна аудієниія в надзвичайно високопоставленого державного мужа (Ю. Андрухович); Зазвичай “маленькі” компанії разом з білетом до Мексики продають квиток на свій внутрішній рейс від, скажімо, Берліну і до отого великого міста, звідки уже “велика” авіакомпанія везе вас далі за океан (М. Кідрук) і под.

Сучасні написання назв деяких міст із флексіями -y (-ю), зауважував I. Р. Вихованець, не сприймаємо як ненормативні, оскільки вони «не спотворюють типового образу української мови» (Теоретична... 2004: 109). 3 огляду на це аналізовану зміну можна кваліфікувати як таку, що віддзеркалює тенденції сучасної мовної практики, хоч, на думку О. О. Тараненка, пересічні мовці вживають в усному й писемному мовленні форм родового відмінка іменників чоловічого роду на $-y(-ю)$ здебільшого спонтанно, не усвідомлюючи повної міри їх «українськості» (Тараненко 2005: 92). 
Зміни в унормуванні закінчень родового відмінка однини в новому «Українському правописі» запроваджено також і для частини іменників жіночого роду III відміни. Зокрема, для фіксованої групи іменників III відміни (кров, любов, осінь, сіль, Русь, Білорусь) та усіх іменників жіночого роду, що закінчуються на -mb із попереднім приголосним (вicmb, padicmb, cмерть, честь, хоробрість і под.), дозволено поряд із закінченням - $i$ як його варіант уживати закінчення -и (Український правопис 2019: 128). На тлі редакції «Українського правопису» 1993 р. ця зміна є нововведенням, адже в ній такого правила не було. Проте якщо проаналізувати інші видання «Українського правопису», то закінчення -и в родовому відмінкові однини іменників жіночого роду на -mb III відміни - це морфологійна норма, що була кодифікована в «Українському правописі» 1928 р. (Український правопис 1929: 35). Саме тому аналізовану зміну дехто 3 мовознавців витлумачує як «спробу повторного нормативного закріплення» у родовому відмінкові однини закінчення $-u$ (замість $-i$ ) у певній частині іменників жіночого роду III відміни (Тараненко 2005: 92).

Однак між правилом, викладеним в «Українському правописі» 2019 р., і правилом, наведеним в «Українському правописі» 1928 р., наявні істотні розбіжності. В «Українському правописі» 1928 р. закінчення - $u$ кодифіковано як єдине закінчення родового відмінка однини для обмеженої групи іменників III відміни (кров, любов, осінь, сіль, Русь) та усіх іменників жіночого роду «на -mь за другим приголосним» (Український правопис 1929: 35), тоді як у новому «Українському правописі» 2019 р. правило про нормативність закінчення - $и$ для іменників жіночого роду III відміни подано у формі примітки, а самому закінченню -и надано статусу варіантного (Український правопис 2019: 128).

Повернення закінчення - $и$ іменникам жіночого роду III відміни в редакції «Українського правопису» 2019 р. грунтоване на історично зумовлених закономірностях розвитку граматичного ладу української мови, зокрема на наявності флексії - $u$ в говірках, що лягли в основу літературної мови, та у творах класиків української літератури (Історія українського правопису 2004: 563). Цю норму фіксують художні, наукові та публіцистичні тексти 20-30 pp. ХХ ст. Вона була чинною до «реформи» 1933 р. Після ухвалення «Українського правопису» 1933 р. нормативним закінченням родового відмінка однини усіх іменників III відміни стало - $i$ (Український правопис 1933: 39).

Потребу повернути іменникам III відміни на -mь у родовому відмінку однини традиційне закінчення - $и$ багато хто з українських мовознавців обстоював ще під час обговорення редакції «Українського правопису» 1996 р. (Бурячок 1997: 28; Горняткевич 1997: 42; Пономарів 1997: 79 та ін.), хоч, на думку декого з них, уведення закінчення - $u$ в родовому відмінку деяких іменників ускладнить українську граматику, створивши мішану групу відмінювання іменників III відміни, а, як відомо, мішаної групи іменники цієї відміни не мають (Баранник 1997: 77; Головащук 1997: 83-84).

У мовній практиці професійної спільноти закінчення - $и$ в родовому відмінкові однини іменників жіночого роду III відміни засвідчене ще задовго до його повторної кодифікації в «Українському правописі» 2019 - від початку 90-х рр. ХХ ст. Ним під час відмінювання іменників жіночого роду III відміни на приголосний найперше послуговувалися ті працівники ЗМI та книжкових видавництв, які прагнули відновити морфологійні норми «Українського правопису» 1928 р., проте й вони, за спостереженнями дослідників, дотримувалися цього правила непослідовно (Тараненко 2005: 94). Мовознавці зафіксували три варіанти вжитку іменників жіночого роду III відміни із закінченням - $u$ : 1) не тільки в межах окресленої нормами «Українського правопису» 1928 р. групи іменників жіночого роду в родовому відмінкові однини; 2) не лише в родовому відмінкові однини; 3) флексію - $и$ постійно спонтанно чергують із флексією $-i$ (там само).

Дехто із сучасних мовців використовує закінчення - $u$ в родовому відмінкові однини, крім визначеного кола іменників жіночого роду, що закінчуються на приголосний, та в усіх іменниках із кінцевим -mb із попереднім приголосним, ще й в інших іменниках жіночого (пам'яти, тіни, печати, стати і под.) та навіть середнього роду IV відміни, під час відмінювання яких 
до основи додають суфікс -ен- (імени, племени, вимени, тімени та ін.), напр.: Нехай ці скромні слова згадки про них будуть вічними в історії намого народу, нехай $і$ їх імена стануть поруч інших, які віддали своє життя нічим ніде не сплямивщи українського імени (Г. Стецюк); «Голод імени Сталіна», як його назвало українське селянство, був лише кульмінаційним пунктом, найдраматичнішим моментом у боротьбі українського народу за право вільно жити на своїи землі (В. Старко) і под. На думку О. О. Тараненка, тенденція вживати іменників середнього роду IV відміни в родовому відмінкові однини із закінченням - $u$ має всі підстави як власне структурно-граматичного плану, так і з погляду традиції нормативного функціонування (Тараненко 2005: 95).

У мовній практиці перших двох десятиріч XXI ст. активізацію вжитку закінчення -и в родовому відмінкові однини іменників жіночого роду III відміни спостерігаємо здебільшого в індивідуальних мовних практиках науковців, напр.: Загальнохристиянські проблеми добра $i$ зла, життя і смерти, любови й ненависти, вірности й зради < .. > оприявнюють ті иінності, які ци для Котляревського-письменника, $i$ для Котляревського-вихователя, $i$ для Котляревського-чиновника, $і$ для Котляревського-офіцера є мірилом вчинків $i$, зрештою, усього життя (М. Степаненко); Шкода, щьо Правописна комісія не наважилася замість невизначеної варіантности запровадити норми, щчо їх давно пропонують $i$ мовознавичі, $i$ фахівиі з різних галузей науки, зокрема термінознавиі (О. Кочерга); Кожному колоративу властивий різний спектр сполучуваности з іншими лексемами (І. Кочан) і под. У мові сучасних ЗМІ це закінчення, навіть попри кодифікацію в новому правописі, так само, як і раніше, уживане рідко, що можна пояснити суб'єктивним чинником стилістично-оцінного сприйняття форм родового відмінка на - $u$ самими мовцями, дехто $з$ яких уважає ці граматичні форми «простонародними», «діалектними й одіозними», «штучними» чи такими, що «призводять до огрублення мови, втрати мелодійності і м'якості їі» (Тараненко 2005: 94).

Саме тому вжиток у родовому відмінкові однини із закінченням - $u$ (замість $-i$ ) деяких іменників жіночого роду III відміни, що закінчуються на приголосний, та всіх іменників із кінцевим -mь із попереднім приголосним, а також іменників середнього роду IV відміни, на противагу проаналізованій вище тенденції до розширеного використання форм родового відмінка іменників чоловічого роду II відміни на $-y(-ю)$, має не спонтанний, а усвідомлений характер, оскільки його намагаються відновити ті мовці, які мають відповідний фаховий рівень і зорієнтовані на відродження питомих граматичних рис української мови. Свою позицію вони обгрунтовують наявністю флексії - $и$ в говірках, що лягли в основу літературної мови, та у творах класиків української літератури, а також потребою усунути омонімію форм родового і давального відмінків цих іменників (пор.: Р. в.: любові, імені - Д. в. : любові, імені) (Головащук 1997: 83; Тараненко 2005: 93), а вжиток закінчення - $и$ в родовому відмінкові однини іменників середнього роду IV відміни - прагненням забезпечити цілісність парадигми IV відміни: ім'я - імени, бо ягня (теля, курча) - ягняти (теляти, курчати) (Німчук 1999: 306). Ба більше, як зауважує О. О. Тараненко, сучасні мовці вживають закінчення -u в таких іменниках не просто цілком усвідомлено, а навіть підкреслено - як «ознаку відданості справжнім, а не накиненим під впливом російської мови нормам української мови», у зв'язку iз чим «факт прийняття / неприйняття цієї граматичної форми набуває характеру політизованості» (Тараненко 2005: 92). За спостереженнями В. В. Німчука, станом на 1999 р. найгостріші суперечки в середовищі фахівців і ширшої громадськости тривали щодо флексій родового відмінка однини іменників III відміни та слів IV відміни з суфіксом -ен- (Німчук 1999: 299). Проте якщо згідно із чинною редакцією «Українського правопису» 2019 р. мовці можуть послуговуватися флексією - и в родовому відмінкові однини іменників жіночого роду III відміни не порушуючи чинної морфологійної норми, то щодо закінчення родового відмінка однини іменників середнього роду IV відміни, під час відмінювання яких до основи додають суфікс -ен-, у новій редакції головного правописного кодексу України зауваг немає.

Істотних змін у новому «Українському правописі» зазнали форми кличного відмінка однини іменників чоловічого роду ІІ відміни - особових імен Ігор та Олег. У попередній 
редакції «Українського правопису» іменник Ігор, хоч і був зарахований до м’якої групи, проте у кличному відмінку він мав закінчення -e, характерне для іменників чоловічого роду ІІ відміни мішаної групи з основою на -р (Український правопис 1993: 109). В «Українському правописі» 2019 р. цю морфологійну невідповідність виправлено. Тепер для іменника Ігор у кличному відмінкові однини як нормативне зафіксоване закінчення -ю (Український правопис 2019: 173). Форма кличного відмінка Ігорю засвідчена мовною практикою професійної спільноти, представники якої, зважаючи на те, що в інших непрямих відмінках це ім'я має закінчення м'якої групи, у кличному відмінкові також почали вживати його із закінченням -ю (Городенська 2017: 42). Проте форму звертання Ігорю мовці використовують ще зрідка, оскільки одні про цю нову форму ще не знають, другі не звикли до неї, а треті - ігнорують.

Чоловіче ім'я Олег донедавна у кличному відмінкові однини мало нормативну форму на -y - Олегу (Український правопис 1993: 108). У новому «Українському правописі» для цього імені запропоновано ще одну, варіантну форму із закінченням -е - Олеже (Український правопис 2019: 172). Причина появи цього варіантного закінчення, на думку мовознавців, зумовлена впливом подібних за структурою іменників - загальних назв, пор.: друг - друже і Олег - Олеже (Городенська 2017: 42). У мовній практиці сьогодення помітно, що форма Олеже істотно потіснила форму Олегу, але й форма Олегу ще зовсім не вийшла з ужитку. Саме тому Українська національна комісія з питань правопису визнала нормативними обидві варіантні форми кличного відмінка: Олеже й Олегу (Городенська 2019: 39), які й кодифіковано в новому «Українському правописі».

До «Українського правопису» 2019 р. внесено зміни щодо форм кличного відмінка іменників чоловічого роду ІІ відміни однини у звертаннях, що складаються з двох загальних назв. Згідно з попередньою редакцією «Українського правопису» 1993 р. у таких звертаннях перше слово завжди потрібно було вживати у формі кличного відмінка, а для другого слова нормативними були два варіанти морфологійних форм: форма кличного відмінка та форма називного відмінка: добродію бригадире (бригадир), пане лейтенанте (лейтенант) (Український правопис 1993: 74). У новому «Українському правописі» 2019 р. цю варіантність усунено й кодифіковано форму кличного відмінка для обох іменників - загальних назв, що входять до складу звертання: добродію бригадире, пане лейтенанте (Український правопис 2019: 124).

Аналогійні зміни віднедавна запроваджено й для форм кличного відмінка іменників чоловічого роду II відміни однини у звертаннях, що складаються із загальної назви та прізвища. Відповідно до «Українського правопису» 1993 р. у таких звертаннях «форму кличного відмінка має тільки загальна назва, а прізвище виступає у формі називного відмінка»: друже Максименко, колего Іваничук, товаришу Гончар (Український правопис 1993: 74), тоді як у редакції «Українського правопису» 2019 р. форму кличного відмінка вможливлено не лише для загальної назви, а й для прізвища (друже Максименку, колего Онишуку, пане Ковалю), хоч водночас дозволено поєднувати форму кличного відмінка іменника - загальної назви та форму кличного відмінка прізвища, тотожну з формою називного відмінка (друже Максименко, колего Онищук, пане Коваль) (Український правопис 2019: 24).

Для іменників жіночого роду I відміни, що так само $є$ загальними назвами та прізвищами й уходять до складу звертань, чинна на сьогодні морфологійна норма, на противагу правилу, викладеному в редакції «Українського правопису» 1993 р., не передбачає варіантности: у таких звертаннях обидва іменники мають форму кличного відмінка, пор.: добродійко Вариводо, пані Гаркуше, поетко Забашто (Український правопис 2019: 109), але добродійко Скирда (Український правопис 1993: 74).

Сучасна мовна практика професійної спільноти аналізовані зміни в закінченнях кличного відмінка не відбиває. Це особливо помітно в офіційно-діловій сфері, в освіті, у публічному офіційному спілкуванні на радіо та телебаченні, в усному професійному мовленні, у мові перекладної телепродукції, де на кінець 80-х рр. ХХ ст. кличний відмінок іменників 
майже не вживали, бо «його під впливом російської мови заступив називний відмінок» (Городенська 2017: 41).

3 кінця 90-х рр. XX ст. кличний відмінок у звертаннях до осіб поступово повертається, проте на цей процес має значний деструктивний вплив людський чинник. Мовці, які не послуговуються формами кличного відмінка, пояснюють це тим, що він, на їхню думку, «не має принципового значення», форми кличного відмінка у звертаннях є «штучними, не завжди природними», або й тим, що не вміють утворювати форми кличного відмінка від імен (Ланова 2010: 57). Дехто зізнається, що вживає називного відмінка у звертаннях до осіб, бо кличний відмінок не використовують у тій місцевості, де цей мовець народився і виріс. Це дуже загрозлива ситуація, оскільки вона спричиняє нівеляцію однієї зі специфічних граматичних особливостей української мови й перешкоджає «збереженню та розвиткові літературного стандарту української мови» (Городенська 2017: 44).

Ще однією зміною морфологійного характеру в новому «Українському правописі» 2019 р. є переведення іменника чоловічого роду II відміни хабар із твердої групи до м'якої (Український правопис 2019: 99), що відповідно зумовило й іншу парадигму його відмінювання, спільну для всіх іменників м'якої групи, пор.: однина - Н. в.: хабар, Р. в.: хабаря, Д. в.: хабареві (хабарю), Ор. в.: хабарем, М. в.: (у, на) хабарі (хабареві), (по) хабарі (хабареві); множина - Н. в.: хабарі, Р. в.: хабарів, Д. в.: хабарям, Ор. в.: хабарями, М. в.: (у, на) хабарях (Городенська 2019: 157).

Ця зміна дає змогу усунути плутанину в ужиткові відмінкових закінчень іменника хабар, яку спостерігаємо в сучасній мовні практиці через те, що одні мовці відмінюють його як іменник II відміни твердої групи [хабара, хабарові (хабару), хабаром, хабарам, хабарами й под.], а інші - як іменник м'якої групи [хабаря, хабареві (хабарю), хабарем, хабарям, хабарями тощо], напр.: Південнокорейський бізнесмен хотів дати хабара президенту Казахстану (газета «Високий Замок», 2001); ...mільки відкрите тестування надасть змогу покласти край хабарам (інтернетівське видання «Український тиждень», 2008); Був прецедент із таким хабаром навіть на День Конституиіï (газета «Україна молода», 2012) і Мера Кам'янки-Бузької затримали з хабарем (газета «Високий Замок», 2006); Переконання у спасенній ролі хабаря (а ще краще - родинних зв'язків або особистого знайомства) народжується із пересвідченоі не одним поколінням недовіри до інституцій суду, медицини, міліиії (інтернетівське видання «Український тиждень», 2008); Обох напередодні затримали під час отримання хабаря (газета «Україна молода, 2010) і под.

Проте зараховувати слово хабар до іменників II відміни твердої групи, на думку К. Г. Городенської, безпідставно, адже в нього так само, як і в іменників чоловічого роду, що належать до м'якої групи цієї ж відміни, наголос із -ар у вихідній формі переходить на закінчення в непрямих відмінках, пор.: буква́р - букваря́, віча́р - вівчаря́, друкар - друкаря́ і хабар -хабаря́ (Городенська 2019: 156).

У новому «Українському правописі» також розмежовано вжиток відмінкових закінчень іменників - назв істот (осіб і неосіб) чоловічого роду II відміни в місцевому відмінкові однини залежно від прийменника (Український правопис 2019: 122-123) та розширено ілюстративний ряд іменників чоловічого і середнього роду, які, поєднуючись із прийменником no, мають варіантні закінчення -y (-ю) та -i (-i) (Український правопис 2019: 122).

Тимчасом у сучасній мовній практиці професійної спільноти значно виразнішою є активізація іншої тенденції - використання в місцевому відмінкові однини іменників - назв неістот чоловічого роду II відміни із закінченнями -овi, -еві (-євi). Хоч і в попередній, і в чинній редакції «Українського правопису» це закінчення санкціоноване лише для іменників - назв неістот із суфіксами -к-, -ак-, -ик-, -ок-, -к(-о), -еньк-, -ечк- (-ечок-) (Український правопис 1997: 73; Український правопис 2019: 121-122), але мовна практика кінця XX - початку XXI ст., зокрема наукові та публіцистичні тексти, засвідчує вжиток із закінченнями -овi, -еві (-євi) усього загалу іменників чоловічого роду II відміни незалежно від наявности в них зазначеного суфікса, пор.: (y, по) краєві; (в, при, по, на) інститутові; (в, при, по, на) уні- 
верситетові; (y, при, на, по) храмові; (y, при) штабові; (на, по) поверхові; (на) сюжетові; (на, в) аналізові; при підметові тощо. Напр.: Під час презентаиії книги Юрія Голобородька «У років своя пам'ять» відеозапитання ознайомили дітей з відомими літераторами, які народились y таврійському краєві... (Офіційний сайт Херсонської обласної бібліотеки для дітей); При храмові діяла школа... (інтернетівське видання «Полтавщина», 21.08.2011); ...відділ морської піхоти при Головному штабові Морського міністерства (П. Гай-Нижник); Відкинути весь абстракціонізм і сконцентруватись на сюжетові (із рецензії, 17.12.2009); Об'єктивна соціолінгвістична оцінка впливу суспільства на мову трунтується на аналізові всіх елементів структури мовної політики (О. Данилевська); Якщзо ж дієслівний компонент подвійного присудка при такому підметові має форму однини (середнього роду або 3 особи), ад'єктив може набувати лише форми орудного відмінка (Н. Кобченко) та ін.

Аналізована тенденція мала статус літературної норми в «Українському правописі» 1928 р. (Український правопис 1929: 39). Вона зафіксована у граматичних описах сучасної української літературної мови (Вихованець, Городенська 2004: 105; Вихованець, Городенська, Загнітко, Соколова 2017: 201-202), проте морфологійні норми нового «Українського правопису» іiі не відбивають.

У новому «Українському правописі» 2019 р. також частково переглянуто норми вжитку закінчень іменників - назв неістот чоловічого роду II відміни у знахідному відмінку однини. По-перше, розширено перелік семантичних груп іменників, які у знахідному відмінку однини можна вживати із закінченням - $a(-я)$ : крім назв побутових предметів, додано назви «дерев, документів та ін.» (Український правопис 2019: 120), що дає змогу поширити це правило також на іменники - назви документів і послуговуватися ними в науковому та офіційноділовому стилях сучасної української літературної мови. А по-друге, скореговано реєстр іменників - назв неістот чоловічого роду II відміни, для яких закінчення - $a(-я)$ у знахідному відмінку однини є нормативним: з нього вилучено словоформи карбования і карбованець, а натомість додано варіантні форми іменників акт і акта, вірш і вірша, довідник і довідника, перстень і персня (там само). Зроблені корекції є принциповими з погляду увідповіднення морфологійних норм сучасної української літературної мови нормам української народної мови, проте вони ще цілковито не відбивають весь обшир цієї історично сформованої граматичної норми.

Використання іменників - назв неістот чоловічого роду II відміни у знахідному відмінкові однини із закінченням родового відмінка - $a(-я)$ у перші двоє десятиріч XXI ст. помітно активізувалося в мові ЗМІ. Українські мовознавці констатують, що від початку 90-х рр. практика використання форм знахідного відмінка на - $a$ (-я) помітно пожвавилася порівняно 3 періодом другої половини 30-80-х рp. ХX ст., однак за поширеністю ще поступається перед періодом 20-х рр. ХХ ст. (Тараненко 2005: 97). Із закінченням - $a$ (-я) у знахідному відмінкові однини мовці найчастіше вживають іменники чоловічого роду II відміни, що позначають частини тіла, побутові речі, меблі, знаряддя праці, одяг та взуття, їжу, рослини, монети, зброю, транспортні засоби, дещо рідше - абстрактні явища та поняття, пор.: ...купив собі новенького японського джипа (телеканал ISTV); ...джип наздогнав ВАЗа (телеканал НТН); ...ххтось підпалив легковика (газета «Гарт», 27.11.2014); У Стрию зловмисник попросив велосипеда, щуоб покататися, і втік на ньому («Львівська газета», 05.07.2016); ...вивісили прапора (телеканал СТБ); ...змайструвала вертикально-осьового генератора, який працює від найлегшого вітру $i$ має практичне застосування (газета «Гарт», 23.04.2015); ...Рома ганяв м'яча... (газета «Гарт», 06.12.2012); Вона [біатлоністка] виграла приза (1-й національний телеканал); ... трека видалено через погану якість виконання (радіо «Ера FM») і под.

Ужиток форми знахідного відмінка іменників на - $a(-я)$ у наукових та науково-популярних текстах сьогодні - це «переважно спорадичне явище, що віддзеркалює або фахову позицію автора, або його мовний смак», тобто ця граматична форма вживана «здебільшого в індивідуальних мовних практиках» (Городенська 2017: 42), пор.: Варіанта із переважно використовуємо між приголосними або групами приголосних попереднього $i$ наступного 
слова (І. Вихованець); Присудок передбачає підмета у формі називного відмінка (К. Городенська); У середині XIX cm. український етнограф П. Єфименко уклав словника, в якому зафіксовано 125 слів німецького походження (Т. Пиц); ...бажання мати під рукою довідника в традииійному форматі (В. Кубайчук) та ін.

До корекцій морфологійних норм у новій редакції «Українського правопису» 2019 р. належить також розширення ілюстративного матеріалу до правил, наведених у попередній редакції «Українського правопису». Зокрема, для іменників - назв свійських тварин жіночого роду I відміни у знахідному відмінкові множини нормативні форми, спільні з формами називного відмінка, відтепер, крім назв «окремих свійських тварин», слушно поширено також на назви «комах» і проілюстровано прикладом - ловити мух (і мухи) (Український правопис 2019: 111). Проте попри ці вмотивовані видозміни до тексту правила введено слова «менш поширену форму» (там само), яких не було в редакції «Українського правопису» 1993 р. (Український правопис 1993: 67). Це доповнення безпідставне, оскільки, як засвідчують фольклорні джерела та матеріали етнографічних збірників, в українській народній мові іменники - назви тварин й істот загалом у знахідному відмінку множини вживані у формі називного, а не родового відмінка набагато ширше, ніж це дозволяє чинна кодифікована морфологійна норма.

Крім того, у новому «Українському правописі» ширше проілюстровано варіантні форми знахідного відмінка множини іменників - назв свійських тварин середнього роду II відміни: до наведених у попередній редакції «Українського правопису» форм іменників чоловічого роду II відміни волів (і воли), коней (і коні) (Український правопис 1993: 76) додано варіантні форми іменників середнього роду - поросяток (і поросятка) (Український правопис 2019: 127).

Чимало помилок у сучасному мововжитку зумовлено неправильним використанням відмінкових закінчень іменників, що поєднуються з числівниками два, три, чотири, пор.: два десятка, два лебедя, три учня, чотири літака, чотири особняка й под. замість правильних відмінкових форм іменників два десятки, два лебеді, три учні, чотири літаки, чотири особняки. Щоб запобігти помилкам такого штибу, обгрунтованим $є$ повернення до «Українського правопису» 2019 р. спеціальної примітки (уваги) щодо нормативних закінчень іменників чоловічого роду, поєднаних із числівниками два, три, чотири (Український правопис 2019: 125), яка була в «Українському правописі» 1928 р. (Український правопис 1929: 40) і якої не було в його попередніх редакціях.

Висновки та перспективи подальших досліджень у цьому напрямі. За останні 100 років у граматичних, зокрема й морфологійних, нормах, попри їхню стабільність на тлі інших мовних норм, сталися зміни, які можна простежити за різними виданнями «Українського правопису». Основною особливістю цих змін $€$ їх зумовленість не внутрішніми законами розвитку української літературної мови, а позамовними чинниками - ідеологією певної історичної доби.

Як відомо, найпомітнішого політичного тиску граматичні норми зазнали внаслідок мовнополітичного курсу Радянського Союзу на зближення російської та української мов, за якого було штучно обмежено у функціюванні форми давального відмінка однини іменників чоловічого роду II відміни із закінченнями -овi, -еві (-євi), знахідного відмінка однини іменників назв неістот чоловічого роду II відміни на - $a(-я)$, знахідного відмінка множини іменників назв істот усіх родів, що збігаються з називним відмінком, родового відмінка однини іменників жіночого роду III відміни із закінченням -u, а також форми кличного відмінка іменників усіх родів. Про це свідчить їх вибіркове фіксування в лексикографічних джерелах радянського періоду та їхній статус другорядних морфологійних форм у граматиках і в «Українському правописі» після $1933 \mathrm{p}$.

Зважаючи на це, під час укладання тексту найголовнішого правописного кодексу України «фахівці мають право не тільки спрощувати й уточнювати правила орфографії, а й надати повнокровне життя тим елементам української мови, які в часи тоталітаризму з політичних міркувань було несправедливо й примусово відтіснено на другий план чи на периферію спіл- 
кування або й зовсім заборонено. І це не є війною з мовою, а плеканням її неповторності й багатства» (Німчук 1999: 332). Проте в новому «Українському правописі» 2019 р. норми вжитку відмінкових закінчень іменників істотно не змінено. Запропоновані зміни переважно не $\epsilon$ принциповими, вони лише удокладнюють, уточнюють і под. правила, викладені в попередніх редакціях «Українського правопису».

Зміни в унормуванні відмінкових закінчень іменників, унесені до нового «Українського правопису» 2019 р., найтісніше пов’язані з нормами «Українського правопису» 1928 р. Проте якщо в ньому вони мали статус основних і навіть єдиних морфологійних норм, то в редакції «Українського правопису» 2019 р. їх подано лише як варіантні до норм попередньої редакції.

Зміни та корекції, запропоновані в новому «Українському правописі», неоднаково корелюють із тенденціями сучасної мовної практики української професійної спільноти: одні 3 них [закінчення $-y(-ю)$ в родовому відмінкові однини іменників - назв населених пунктів чоловічого роду II відміни, закінчення - $u$ в родовому відмінкові однини іменників жіночого роду III відміни] відбиті в ній ще до їх повторної кодифікації в новому «Українському правописі»; другі (зміни в ужиткові закінчень кличного відмінка) унаслідок граматичного спадку, сформованого в радянський період, та деструктивного впливу людського чинника ще слабко підтримані мовною практикою професійної спільноти; треті [використання форм знахідного відмінка на - $a(-я)$ для іменників - назв неістот чоловічого роду II відміни та форм знахідного відмінка множини іменників - назв тварин усіх родів, що збігаються з називним відмінком] у мовній практиці українців представлені значно ширше, ніж це відбито в чинному «Українському правописі».

У цій статті ми зосередили увагу на передумовах змін в унормуванні відмінкових закінчень іменників, унесених до нового «Українського правопису» 2019 р., їх співвіднесеності 3 тенденціями мовної практики професійної спільноти. Перспективу подальших наукових студій убачаємо в аналізуванні реальних фактів дотримання офіційно затверджених морфологійних змін представниками свідомої частини українського мовного соціуму.

\section{Література}

Баранник, Дмитро X. «Новий український правопис чи нова редакція “Українського правопису"?». [В:] Український правопис: так $i$ ні: Обговорення нової редакиї «Украӥнського правопису». Київ : УНВЦ «Рідна мова» : Довіра, 1997, 76-78.

[Barannyk, Dmytro Kh. «Novyi ukrainskyi pravopys chy nova redaktsia "Ukrainskoho pravopysu"?» [V:] Ukrainskyi pravopys: tak $i$ ni: Obhovorennia novoi redaktsii «Ukrainskoho pravopysu». Kyiv : UNVTS «Ridna mova» : Dovira, 1997, 76-78.]

Бурячок, Андрій А. «Про концепцію нової (остаточної) редакції українського правопису». [B:] Украӥнський правопис: так і ні: Обговорення нової редакції «Украӥнського правопису». Київ : УНВЦ «Рідна мова» : Довіра, 1997, 26-30.

[Buriachok, Andrii A. «Pro kontseptsiiu novoi (ostatochnoi) redaktsii ukrainskoho pravopysu». [V:] Ukrainskyi pravopys: tak i ni: Obhovorennia novoi redaktsii «Ukrainskoho pravopysu». Kyiv : UNVTS «Ridna mova» : Dovira, 1997, 26-30.]

Вихованець I., Городенська К. Теоретична морфологія української мови. Київ : Пульсари, 2004.

[Vykhovanets, I., Horodenska, K. Teoretychna morfolohiia ukrainskoi movy. Kyiv : Pulsary, 2004.]

Вихованець, І. Р., Городенська, К. Г., Загнітко, А. П., Соколова, С. О. Граматика сучасної української літературної мови. Морфологія. Київ : Видавничий дім Дмитра Бураго, 2017.

[Vykhovanets, I. R, Horodenska, K. H., Zahnitko, A. P., Sokolova, S. O. Hramatyka suchasnoi ukrainskoi literaturnoi movy. Morfolohiia. Kyiv : Vydavnychyi dim Dmytra Buraho, 2017. ]

Головащук, Сергій І. «До правопису закінчень відмінюваних слів». [В:] Украӥнський правопис: так $i$ ні: Обговорення нової редакиії «Українського правопису». Київ : УНВЦ «Рідна мова»: Довіра, 1997, 81-86. 
[Holovashchuk, Serhii I. «Do pravopysu zakinchen vidminiuvanykh sliv». [V:] Ukrainskyi pravopys: tak $i$ ni: Obhovorennia novoi redaktsii «Ukrainskoho pravopysu». Kyiv : UNVTS «Ridna mova» : Dovira, 1997, 81-86.]

Горняткевич, Андрій. «[Виступ]». [В:] Український правопис: так і ні: Обговорення нової редакиї «Украӥнського правопису». Київ : УНВЦ «Рідна мова»: Довіра, 1997, 41-44.

[Horniatkevych, Andrii. «[Vystup]». [V:] Ukrainskyi pravopys: tak i ni: Obhovorennia novoi redaktsii «Ukrainskoho pravopysu». Kyiv : UNVTS «Ridna mova» : Dovira, 1997, 41-44.]

Городенська, Катерина. «Граматичні норми української літературної мови і сучасна практика професійної спільноти». Дивослово 4, 2017: 40-45.

[Horodenska, Kateryna. «Hramatychni normy ukrainskoi literaturnoi movy i suchasna praktyka profesiinoi spilnoty». [V:] Dyvoslovo 4, 2017: 40-45.]

Городенська, Катерина. Українське слово у вимірах сьогодення. Видання друге, істотно доповнене. Київ : КММ, 2019.

[Horodenska, Kateryna. Ukrainske slovo u vymirakh sohodennia. Vydannia druhe, istotno dopovnene. Kyiv : KMM, 2019. ]

Історія українського правопису: XVI-XX століття. Хрестоматія. Київ : Наукова думка, 2004.

[Istoriia ukrainskoho pravopysu: XVI-XX stolittia. Khrestomatiia. Kyiv : Naukova dumka, 2004.]

Ланова, Тетяна. «Актуалізовані граматичні форми в мовленні викладачів ВНЗ (соціолінгвістичне дослідження)». [В:] Науковий вісник Херсонського державного університету: зб. наук. пр. Херсон : Вид-во ХДУ, 2010. Вип. 12. Серія «Лінгвістика», 55-61.

[Lanova, Tetiana. «Aktualizovani hramatychni formy $\mathrm{v}$ movlenni vykladachiv VNZ (sotsiolinhvistychne doslidzhennia». [V:] Naukovyi visnyk Khersonskoho derzhavnoho universytetu: zb. nauk. pr. Kherson : Vyd-vo KhDU, 2010. Vyp. 12. Seriia «Linhvistyka», 55-61.]

Німчук, Василь В. «Проблеми українського правопису в ХХ ст.». [В:] Украӥнський правопис (проєкт найновішої редакиії). Київ, 1999, 242-333.

[Nimchuk, Vasyl V. «Problemy ukrainskoho pravopysu v XX st.». [V:] Ukrainskyi pravopys (proiekt nainovishoi redaktsii). Kyiv, 1999, 242-333.]

Пономарів, Олександр Д. «Пропозиції до нової редакції “Українського правопису”». [В:] Український правопис: так і ні: Обговорення нової редакції «Українського правопису». Київ : УНВЦ «Рідна мова»: Довіра, 1997, 79-81.

[Ponomariv, Oleksandr D. «Propozytsii do novoi redaktsii "Ukrainskogo pravopysu"». [V:] Ukrainskyi pravopys: tak $i$ ni: Obhovorennia novoi redaktsii «Ukrainskoho pravopysu». Kyiv: UNVTS «Ridna mova» : Dovira, 1997, 79-81.]

Синявський, Олекса. «Коротка історія “Українського правопису”». [В:] Iсторія українського правопису: XVI-XX століття. Хрестоматія. Київ : Наукова думка, 2004, 432-452.

[Syniavskyi, Oleksa. "Korotka istoria "Ukrainskogo pravopysu"». [V:] Istoriia ukrainskoho pravopysu: XVI-XX stolittia. Khrestomatiia. Kyiv : Naukova dumka, 2004, 432-452.]

Тараненко, Олександр О. «Сучасні тенденції до перегляду нормативних засад української літературної мови і явище пуризму (у межах граматичних категорій іменника)». Мовознавство 3-4: 2005, 85-104.

[Taranenko, Oleksandr O. «Suchasni tendentsii do peregliadu normatyvnykh zasad ukrainskoi literaturnoi movy i yavyshche puryzmu (u mezhakh gramatychnykh kategorii imennyka)». Movoznavstvo 3-4: 2005, 85-104.]

Український правопис. Видання перше. Харків : Державне видавництво України, 1929.

[Ukrainskyi pravopys. Vydannia pershe. Kharkiv : Derzhavne vydavnytstvo Ukrainy, 1929.]

Український правопис. Харків : Радянська школа, 1933.

[Ukrainskyi pravopys. Kharkiv : Radianska shkola, 1933.]

Український правопис. 4-те вид., випр. й доп. Київ : Наукова думка, 1993.

[Ukrainskyi pravopys. 4-te vyd., vypr. i dop. Kyiv : Naukova dumka, 1993.]

Український правопис. Київ : Наукова думка, 2019.

[Ukrainskyi pravopys. Kyiv : Naukova dumka, 2019.] 


\section{CHANGES IN THE CODIFICATION OF CASE ENDINGS OF NOUNS ON THE BACKGROUND OF THE MODERN LANGUAGE PRACTICE OF THE UKRAINIAN PROFESSIONAL COMMUNITY}

\section{Larysa Kolibaba}

Department of Grammar and Scientific Terminology, Institute of the Ukrainian Language of National Academy of Sciences of Ukraine, Kyiv, Ukraine

\section{Abstract}

Background: In the new "Ukrainian spelling" of 2019 the most noticeable changes in the codification of morphological norms of the modern Ukrainian literary language concern the case endings of nouns. However, most of these changes are not cardinal; they only modify the morphological norms set out in previous editions of the "Ukrainian spelling".

Purpose: The purpose of this article is to analyze the main changes in the codification of case endings of nouns, recorded in the new "Ukrainian spelling" of 2019, on the background of historically formed grammatical features of the Ukrainian language and the modern language practice professional community - speakers, who have professional knowledge of the Ukrainian language and adhere to literary language norms in their professional activities.

Results: We divided all changes in the text of "Ukrainian spelling" of 2019 depending on the degree of their importance into two groups: actually changes - a new norms, that were not in the edition of "Ukrainian spelling" of 1993, and corrections - clarification and reformulation of substance of the rules present in the previous spelling code, introduction of variant morphological forms, expansion of illustrative material, etc.

As actually changes in the "Ukrainian spelling" of 2019 can be qualified new rules for writing endings of the genitive case of the singular of some masculine nouns of the second declension and part of feminine nouns of the third declension, as well as the endings of the vocative case of the singular of some nouns - masculine personal names of the second declension, masculine nouns of the second declension and feminine nouns of the first declension in appeals consisting of two names. Corrections are made regarding the spelling of the endings of the accusative and the locative cases of the singular and the nominative case of the plural of masculine nouns of the second declension, as well as the accusative case of the plural nouns - names of feminine animals of the first declension.

Discussion: Analyzed morphological changes in the new "Ukrainian spelling" most closely related to the norms of "Ukrainian spelling" of 1928. However, if in it they had the status of basic and even only morphological norms, then in the edition of "Ukrainian spelling" of 2019 they presented as variants to the norms of the previous edition.

The proposed changes and corrections in the normalization of case endings of nouns differently correlate with the trends of the modern language practice of the Ukraine professional community: the some of them are reflected in it before their codification in the new "Ukrainian spelling", the second, owing to grammatical heritage, formed in the Soviet period, and destructive influence of the human factor, still weakly supported by the language practice of the professional community, the third in the language practice of Ukrainians are presented considerably wider than it is done in the valid "Ukrainian spelling".

We see the prospect of further research in the analysis of the real facts of compliance of officially approved morphological changes by representatives of the conscious part of the Ukrainian language society.

Keywords: morphological norms, ending, "Ukrainian spelling”, language practice, professional community.

\section{Vitae}

Larysa Kolibaba is Candidate of Philology, Senior Research Fellow of Department of Grammar and Scientific Terminology at Institute of the Ukrainian Language of National Academy of Sciences 
of Ukraine. Her areas of research interests include theoretical and practical problems of morphology, derivatology, culture of the modern Ukrainian literary language, grammatical lexicography.

Correspondence: kolibaba79@gmail.com

Надійшла до редакції 19 березня 2021 року

Рекомендована до друку 2 квітня 2021 року

Nataliia Lazebna

ORCID: https://orcid.org/0000-0001-5886-693X

DOI 10.31558/1815-3070.2021.41.5

УДК 811.111

\section{HUMAN COMPETENCES IN ENGLISH-LANGUAGE NOUN PHRASES USE}

Розглянуто особливості сприйняття англомовних номінативних фраз, їх морфологічних характеристик та синтаксичних функиій. Проаналізована специфіка продукування та використання іменних фраз англійської мови (NP). Іменник як ядро досліджуваних фраз виступає важливим ідентифікатором інформації, що передається. Створення іменних фраз респондентами свідчить про морфологічну обізнаність мовиів, і про певні труднощі при аналізі синтаксичних функиій іменних конструкиій. Помилки у аналізі англомовних іменних конструкиій корелюються із мовленнсвими зразками рідної (украӥнської) мови і інтерферуються із граматичними нормами англійської мови.

Ключові слова: іменні фрази, морфологічна обізнаність, синтаксична функиія, мовні зразки.

\section{Introduction}

Humans, by developing their abilities to use noun phrases, foster their knowledge of English, to apply it appropriately and proactively. Nomination refers to a special way of lexical and grammatical meaning conveyance. The main means of information transfer in English is a noun. The process of nomination and expression of thoughts facilitates the world's cognition and description. Both, syntactic and nominative functions create an inseparable and harmonious meaningful unity. The language arises from speech and it evokes a new system of relevant features. Language learners should be able to apply a wide arsenal of tools and instruments, which effectively transfer their ideas, help them share the information, and communicate with others.

Noun phrases (NP) represent the object of this research paper. The learners of English as a foreign language (EFL students) should be aware of NPs specifics and implement them effectively. Being one of the basic tools of the English language, a noun represents an important identifier of the information sent to the recipient. NP is an integrative step on the way to correct sentence formation. Syntactic and morphological features of NPs are considered to represent the subject of this paper. Based on questionaries, the speech of EFL students is often predetermined by the studied grammar structures, but the students develop their speaking patterns according to their needs, experience, heard/read patterns, or standards. An innovative perspective stems from NPs use by EFL learners. Theoretical underpinnings of the Eastern and Western researchers enable to conduct an objective evaluation of the NPs perception, use, and further functioning as one of the most important tools of the world cognition. Theoretical integration of the world's leading ideas in the field of nomination, as well as its further practical implementation in the context of the study, signify its wide scope of concern. 